\title{
Combined effect of temperature and salinity on hatching characteristics of three fairy shrimp species (Crustacea: Anostraca)
}

\author{
Behroz ATASHBAR,,${ }^{1 * *}$ Naser AGH, ${ }^{2}$ Gilbert Van STAPPEN,${ }^{3}$ Johan MERTENS, ${ }^{1}$ Lynda BELADJAL ${ }^{1}$ \\ ${ }^{1}$ Department of Biology, Faculty of Science, Ghent University, K.L. Ledeganckstraat 35, 9000 Gent, Belgium; ${ }^{2}$ Department of Biol- \\ ogy, Urmia Lake Research Institute, Urmia University, Urmia 57179-44514, Iran; ${ }^{3}$ Laboratory of Aquaculture \& Artemia Reference \\ Center, Ghent University, Rozier 44, 9000 Gent, Belgium \\ *Corresponding author: behroz.atashbarkangarloei@UGent.be; B.atashbar@urmia.ac.ir
}

\begin{abstract}
The combined effects of temperature and salinity on hatching performance of three anostracan species, Phallocryptus spinosa, Branchinecta orientalis and Streptocephalus torvicornis from East and West Azerbaijan, Iran, were studied. The cysts were kept for 10 days at seven different temperatures $\left(12,15,18,21,24,27\right.$ and $\left.30^{\circ} \mathrm{C}\right)$ and four salinity conditions $(0,5,10$, and $15 \mathrm{gL}-1)$, and the effects of the resulting 28 experimental conditions on hatching patterns (duration of pre-hatching period, hatching percentage at first day of hatching, cumulative hatching success) were examined. Results were tested by ANOVA and multiple regression was applied to generate contour models by polynomial equation. The hatching performance in all species was significantly affected by temperature and salinity. Based on contour plot analysis, maximum hatching for $\mathrm{P}$. spinosa, B. orientalis and $\mathrm{S}$. torvicornis cysts was registered at temperatures $19-25^{\circ} \mathrm{C}, 18-23^{\circ} \mathrm{C}$ and $16-20^{\circ} \mathrm{C}$, respectively, within the same salinity range of $0-1 \mathrm{gL} \mathrm{L}^{-1}$. The highest cumulative hatching success among the species was observed in $\mathrm{P}$. spinosa at the combination of $24^{\circ} \mathrm{C}$ and $0 \mathrm{~g} \mathrm{~L}^{-1}$ (88. 98\%). No hatching was observed for eggs of $\mathrm{S}$. torvicornis and $\mathrm{B}$. orientalis incubated at lower $\left(<15^{\circ} \mathrm{C}\right)$ and higher $\left(>27^{\circ} \mathrm{C}\right)$ temperature, respectively. The pre-hatching period was prolonged with increase in salinity and decrease in temperature and was highest in P. spinosa (7.7 days at $12^{\circ} \mathrm{C}$ and $15 \mathrm{gL} L^{-1}$ salinity). High hatching success was observed over wide ranges of temperature and salinity in P. spinosa eggs which demonstrates one of the possible mechanisms responsible for the wide distribution of this species.
\end{abstract}

Key words: Anostraca, Phallocryptus spinosa, Branchinecta orientalis, Streptocephalus torvicornis, cumulative hatch.

Received: January 2014. Accepted: May 2014.

\section{INTRODUCTION}

Fairy shrimp (Branchiopoda: Anostraca) are often the most conspicuous invertebrates associated with the temporary aquatic habitats that are typically characterized by variation in timing, frequency and duration of inundations; a number of variables that together shape the hydrological regime (i.e., hydroregime) of the habitat (Hulsmans et al., 2008). Like many other diapausing crustaceans, anostracans produce encysted embryos that can remain viable in the sediments for years (Marcus, 1996), providing a significant source of recruitment to the water column (Viitasalo, 1992) and of dispersal in time (Hairston and Cáceres, 1996). For most of the year, anostracan cysts are far more accessible than the corresponding adult or juvenile forms due to the much longer dry season when compared to the length of the inundated phase (Simovich and Hathaway, 1997).

The distribution of large branchiopods is affected by their drought-resistant cysts, which are efficient agents of passive dispersal, so that populations occur on remote islands, and are apparently found wherever there are suitable habitats (Longhurst, 1955). The diapausing cysts may be dispersed by wind, water or birds, which regularly visit seasonal water bodies (Proctor, 1964; Proctor et al., 1967; Figuerola et al., 2003; Green and Figuerola, 2005; Green et al., 2005). Furthermore the extremely sticky eggs could also disperse presumably by adhering to land animals (Longhurst, 1955; Frank, 1988; Gottwald and Eder, 1999; Bohonak and Roderick, 2001; Coulson et al., 2002). Dormancy ends when the appropriate environmental cues (e.g., light, temperature) occur with hydration (Brendonck, 1996; Brendonck et al., 1996, 1998; Hathaway and Simovich, 1996). A certain fraction of the eggs resumes metabolism when favourable environmental conditions are restored, while others remain paused until one or more seasonal cycles have passed. This observed delay in cyst hatching is supposed to be an adaptation to overcome unpredictable seasonal changes that could be fatal for the adult life-phase. In this sense, the existence of a marked inter- and intraspecific variation observed in the hatching pattern of fairy shrimps (Merta, 2003; Zarattini, 2004; Zarattini and Mura, 2007), has provided evidence that a different cyst reactiveness exists, and this is related to the degree of environmental unpredictability (Belk and Cole, 1975).

Little is known regarding the environmental conditions 
present in temporary ponds that may stimulate hatching of resting eggs. Some variables, such as temperature (Brendonck et al., 1998) and salinity level (Nielsen et al., 2003) have been suggested as hatching cues for temporary pool invertebrates. The influence of temperature and salinity levels on hatching of resting eggs has been studied in zooplankton such as Artemia (Sorgeloos et al., 1980; Abatzopoulos et al., 2003), copepods (Grice and Marcus, 1981; Hansen et al., 2010) and rotifers (Lubzens et al., 1980; Pourriot and Snell, 1983; Garcia-Roger et al., 2006). However, high variability in hatching behavior and lack of ecological background information of the test species make it difficult to generalize or to correlate hatching characteristics with environmental conditions (Bond, 1934).

Three fairy shrimp species, Phallocryptus spinosa Milne Edwards, 1840, Branchinecta orientalis G. O. Sars 1901 and Streptocephalus torvicornis Waga, 1842 (Mura and Azari Takami, 2000; Mehdizadeh Fanid et al., 2007; Atashbar et al., 2014) live in temporary wetlands whose hydroregimes patterns are extremely unpredictable and which often fill in the early spring and dry in the summer time. P. spinosa occurs in fresh, brackish to saline waters, while $B$. orientalis and $\mathrm{S}$. torvicornis are found in fresh to brackish water pools. Field studies and personal observation demonstrate that in $P$. spinosa and $S$. torvicornis cysts hatch through mid-spring and adult fairy shrimps may persist into the summer but are usually hard to find after July. In contrast, hatching of B. orientalis occurs through the late winter from March to May and the adults usually start disappearing from the ponds in early May.

There are no literature data available on the reproductive characteristics and hatching performances of Iranian P. spinosa, B. orientalis, and S. torvicornis. Hence, our experiment aimed to test the impact of critical environmental factors such as salinity and water temperature, on the hatching characteristics of these species of fairy shrimps.

\section{METHODS}

\section{Study sites}

Diapausing eggs of the three anostracan species, Streptocephalus torvicornis, Phallocryptus spinosa and Branchinecta orientalis were collected from the sediments of three water bodies located in the northwestern region of Iran (East and West Azerbaijan) (Fig. 1). All these habitats had been previously identified through live animal samplings performed during the wet period. Each locality was visited 4-5 times during April-May. Length and width of each pool were measured to estimate surface area as the surface area of an ellipse. Temperature was measured using sensors (Crison MM40, Alella, Barcelona, Spain). A hand refractometer (Atago, Tokyo,
Japan) was used to measure salinity. During the desiccation process, water salinity increased up to levels as high as $40-60 \mathrm{gL}^{-1}$ in different biotopes. Altitude and coordinates were measured using a portable GPS (Garmin, Olathe, KS, USA) (Tab. 1).

\section{Hatching experiments}

The soil containing cysts of anostracans was collected in August after complete drying out of the habitat. The soil samples were transferred into a 300-L tank filled with tap water and subsequently washed over 500 and $150 \mu \mathrm{m}$ sieves to collect the eggs. The separated dormant eggs were dried at $37^{\circ} \mathrm{C}$ in an incubator (Munuswamy et al., 2009) and kept in a refrigerator at $4^{\circ} \mathrm{C}$ for one month (Atashbar et al., 2012).

Hatching fractions were compared in a multifactorial design at seven temperatures $(12,15,18,21,24,27$ and $\left.30^{\circ} \mathrm{C}\right)$ and four salinity conditions $\left(0,5,10\right.$, and $15 \mathrm{gL}^{-1}$; prepared by dissolving Urmia Lake salt in dechlorinated tap water under constant fluorescent light (Atashbar et al., 2012). The choice of these salinity levels was inspired by the salinity registered after inundation of the habitats. The selected temperatures were based on field records collected when the first stages of the fairy shrimps were observed in the pools. Hatching under experimental temperatures was performed in six replicates of 30 dormant eggs each, incubated in multi-well $(10 \mathrm{~mL})$ plastic trays for a period of 10 days (Hulsmans et al., 2006; Atashbar et al., 2012). The numbers of hatched nauplii were counted, expressed as percentage, and they were removed from the hatching trays daily. Dormant eggs that remained unhatched at the end of the experiment were tested for their viability by checking for the presence

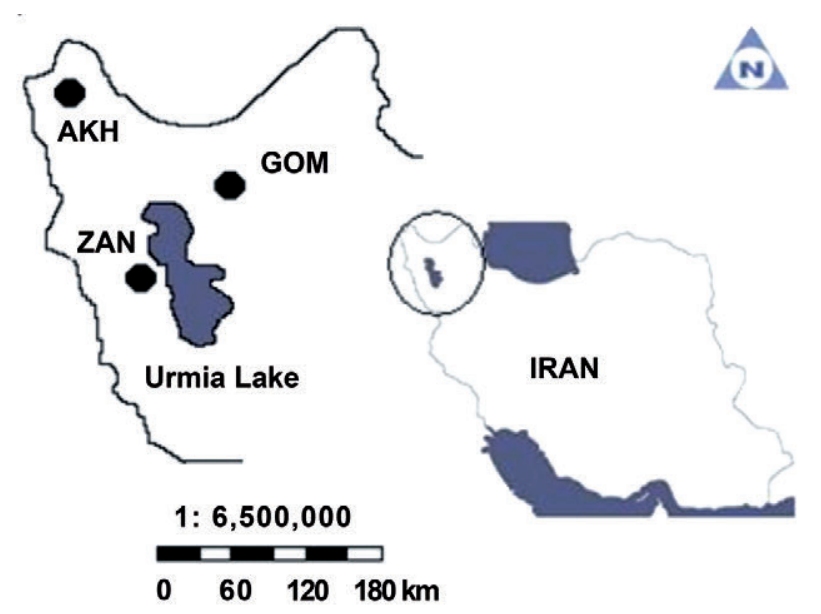

Fig. 1. Location of sampling sites in East Azerbaijan (Akh Gol: AKH; Zanbil: ZAN) and West Azerbijan (Gom Tapa: GOM). 
of a yolky embryo according to the method described by Van Stappen (1996). Hatching performance was corrected based on the number of empty eggs found in each sample (Van Stappen, 1996).

\section{Statistical analysis}

Temperature and salinity effects on dependent variables (pre-hatching period, hatching percentage at the first day, and cumulative hatching percentage on day 10) were tested by 2 -way factorial ANOVA (followed by Tukey test $(\mathrm{P}<0.05)$, in order to determine the differences between the treatments). For all dependent variables expressed as percentages the assumption of normal distribution within groups was fulfilled (KolmogorovSmirnov test for normality) and the Levene's test was used to assess of the homogeneity of variances. Regression coefficients were used in the polynomial expression to generate a surface response contour:

$$
\mathrm{Z}\left(\mathrm{H}_{\mathrm{CUM}} \%\right)=\mathrm{b}_{0}+\mathrm{b}_{1}(\mathrm{~T})+\mathrm{b}_{2}(\mathrm{~S})+\mathrm{b}_{3}\left(\mathrm{~T}^{2}\right)+\mathrm{b}_{4}\left(\mathrm{~S}^{2}\right)+\mathrm{b}_{5}(\mathrm{TxS})
$$

where $\mathrm{Z}\left(\mathrm{H}_{\mathrm{CUM}} \%\right)$ is the surface response of the cumulative hatching percentage, $\mathrm{T}$ is temperature, $\mathrm{S}$ is salinity, $b_{0}$ is the multiple regression constant, $b_{1}$ and $b_{2}$ are the linear effects of temperature and salinity, $b_{3}$ and $b_{4}$ are the quadratic effects, and $b_{5}$ is the intersection effect.
Results were analyzed using software package Statistica 10 (Stat Soft, Inc., Tulsa, Oklahoma, USA).

\section{RESULTS}

\section{Day of first hatching}

An overall significant effect of temperature and salinity on pre-hatching period was observed, as well as a significant interaction effect, for $B$. orientalis, $P$. spinosa and $S$. torvicornis (ANOVA, $\mathrm{P}<0.001$ ) (Tab. 2).

The pre-hatching period of the three mentioned species is illustrated in Fig. 2. In B. orientalis hatching started first at $27^{\circ} \mathrm{C}$ and at salinity $0 \mathrm{gL}^{-1}(1.56 \pm 0.20$ days after inundation) and was slowest to start at the combination of $15^{\circ} \mathrm{C}$ and $10 \mathrm{gL}^{-1}$ (5.51 1.00 days after inundation). In general, no hatching occurred at all at $30^{\circ} \mathrm{C}$. No hatching was detected at the highest salinity tested $\left(15 \mathrm{gL}^{-1}\right)$ in combination with lower and higher temperature conditions $\left(12,15\right.$ and $\left.27,30^{\circ} \mathrm{C}\right)$. In $P$. spinosa the pre-hatching period ranged from 1 day after inundation at $30 \pm 0.1^{\circ} \mathrm{C}$ and $0 \mathrm{gL}^{-1}$, to $7.72 \pm 1.52$ days for the combination $12^{\circ} \mathrm{C}$ and $15 \mathrm{gL}^{-1}$. In $S$. torvicornis no hatching was observed at salinity higher than $5 \mathrm{gL}^{-1}$ and also at $12^{\circ} \mathrm{C}$. Hatching in this species started 1 day after inundation in most of the treatments and was slowest at $15^{\circ} \mathrm{C}$ at salinities 0 $(2.33 \pm 0.40)$ and $5 \mathrm{gL}^{-1}(4.13 \pm 1.41)$ (Tukey, $\mathrm{P}<0.05$ ).

Tab. 1. Location and characteristics of sampling sites in the study area during April-May.

\begin{tabular}{|c|c|c|c|c|c|c|c|c|}
\hline Species & Locality & Code & $\mathrm{N}^{\mathrm{Co}}$ & tes & $\begin{array}{c}\text { Temperature } \\
\left({ }^{\circ} \mathrm{C}\right)\end{array}$ & $\begin{array}{l}\text { Salinity } \\
\left(\mathrm{gL}^{-1}\right)\end{array}$ & $\begin{array}{l}\text { Altitude } \\
\text { (m.a.s.l) }\end{array}$ & $\begin{array}{l}\text { Surface area } \\
\qquad\left(\mathrm{m}^{2}\right)\end{array}$ \\
\hline B. orientalis & $\begin{array}{c}\text { Akh Gol } \\
\text { (East Azerbaijan) }\end{array}$ & $\mathrm{AKH}$ & $39^{\circ} 33^{\prime}$ & $44^{\circ} 44^{\prime}$ & $21-27$ & $1-2$ & 800 & 600,000 \\
\hline P. spinosa & $\begin{array}{c}\text { Zanbil } \\
\text { (West Azerbaijan) }\end{array}$ & ZAN & $37^{\circ} 44^{\prime}$ & $45^{\circ} 15^{\prime}$ & $14-28$ & $3-30$ & 1300 & 25,037 \\
\hline S. torvicornis & $\begin{array}{c}\text { Gom Tapa } \\
\text { (East Azerbaijan) }\end{array}$ & GOT & $38^{\circ} 13^{\prime}$ & $46^{\circ} 02^{\prime}$ & $22-26$ & $0-2$ & 1297 & 2100 \\
\hline
\end{tabular}

Tab. 2. ANOVA analyses testing the effects of temperature and salinity on pre-hatching period.

\begin{tabular}{|c|c|c|c|c|c|}
\hline Species & $\begin{array}{l}\text { Source of } \\
\text { variation }\end{array}$ & $\begin{array}{l}\text { Degrees of } \\
\text { freedom }\end{array}$ & $\begin{array}{l}\text { Mean sum of } \\
\text { squares }\end{array}$ & $\begin{array}{c}\mathrm{F} \\
\text { value }\end{array}$ & $\begin{array}{c}\mathrm{P} \\
\text { value }\end{array}$ \\
\hline B. orientalis & $\begin{array}{c}\text { Temperature } \\
\text { Salinity } \\
\text { Temperaturexsalinity }\end{array}$ & $\begin{array}{c}6 \\
3 \\
18\end{array}$ & $\begin{array}{l}41.80 \\
22.50 \\
13.43\end{array}$ & $\begin{array}{l}53.20 \\
17.09 \\
16.76\end{array}$ & $\begin{array}{l}\mathrm{P}<0.001 \\
\mathrm{P}<0.001 \\
\mathrm{P}<0.001\end{array}$ \\
\hline P. spinosa & $\begin{array}{c}\text { Temperature } \\
\text { Salinity } \\
\text { Temperaturexsalinity }\end{array}$ & $\begin{array}{c}6 \\
3 \\
18\end{array}$ & $\begin{array}{l}82.62 \\
16.85 \\
0.640\end{array}$ & $\begin{array}{l}147.2 \\
30.78 \\
1.168\end{array}$ & $\begin{array}{l}\mathrm{P}<0.001 \\
\mathrm{P}<0.001 \\
\mathrm{P}<0.001\end{array}$ \\
\hline S. torvicornis & $\begin{array}{c}\text { Temperature } \\
\text { Salinity } \\
\text { Temperaturexsalinity }\end{array}$ & $\begin{array}{c}6 \\
3 \\
18\end{array}$ & $\begin{array}{c}5.90 \\
32.91 \\
2.76\end{array}$ & $\begin{array}{c}43.10 \\
240.39 \\
20.14\end{array}$ & $\begin{array}{l}\mathrm{P}<0.001 \\
\mathrm{P}<0.001 \\
\mathrm{P}<0.001\end{array}$ \\
\hline
\end{tabular}




\section{Hatching percentage at first day of hatching}

An overall significant effect of temperature and salinity on hatching percentage at the first day of hatching was observed, as well as a significant interaction between both factors for all species (ANOVA, $\mathrm{P}<0.001$, Tab. 3).

In $B$. orientalis the initial hatching fraction was higher at $21^{\circ} \mathrm{C}$ and $0 \mathrm{gL}^{-1}(56.28 \pm 19.41 \%)$ compared to all others and was lowest at $27^{\circ} \mathrm{C}$ and $10 \mathrm{gL}^{-1}(2.32 \pm 3.62 \%)$. No hatching was observed at $30^{\circ} \mathrm{C}$ in combination with all salinity levels. No hatching at the first day of incubation was observed also at 12,15 and $27^{\circ} \mathrm{C}$ in combination with $15 \mathrm{gL}^{-1}$. In $P$. spinosa it was highest at $27^{\circ} \mathrm{C}$ and $0 \mathrm{gL}^{-1}$ $(70.31 \pm 19.08 \%)$ and lowest at $30^{\circ} \mathrm{C}$ and $15 \mathrm{gL}^{-1}$ $(0.50 \pm 1.45 \%)$. In $S$. torvicornis the initial hatching fraction was higher at $18^{\circ} \mathrm{C}$ and $0 \mathrm{gL}^{-1}(48.70 \pm 20.43 \%)$ than in the other conditions others and lowest at $30^{\circ} \mathrm{C}$ and $5 \mathrm{gL}^{-1}(7.46 \pm 5.38 \%)$. In the latter species no hatching was observed at salinities of 10 and $15 \mathrm{gL}^{-1}$ (Fig. 3).

\section{Cumulative hatching percentage}

Overall the analysis of variance for cumulative hatching percentage produced a fully significant matrix for species, factors and their interaction $(\mathrm{P}<0.001)$ (Tab. 4). In $B$. orientalis cumulative hatching was highest at the combination of $21^{\circ} \mathrm{C}$ and $0 \mathrm{gL}^{-1}(79.70 \pm 12.47 \%)$ and lowest at $24^{\circ} \mathrm{C}$ and $15 \mathrm{gL}^{-1}(1.67 \pm 4.08 \%)$. No hatching occurred at $30^{\circ} \mathrm{C}$ at any salinity. The multiple comparisons test showed a significant difference between $18^{\circ} \mathrm{C}$ and all other treatment groups based on observed means. Significant differences were also seen within the salinity groups (Tukey, $\mathrm{P}<0.05$ ). For $P$. spinosa the cumulative hatching percentage was highest at the combination of $24^{\circ} \mathrm{C}$ and $0 \mathrm{gL}^{-1}(88.98 \pm 22.50 \%)$ and lowest at $30^{\circ} \mathrm{C}$ and $15 \mathrm{gL}^{-1}(0.59 \pm 1.46 \%)$ compared to the other treatments. The mean differences were significant within the salinity levels (Tukey, $\mathrm{P}<0.05$ ). In $S$. torvicornis, finally, it was higher at $18^{\circ} \mathrm{C}$ and $0 \mathrm{gL}^{-1}(67.07 \pm 14.18 \%)$ and lower at $30^{\circ} \mathrm{C}$ and $5 \mathrm{gL}^{-1}(7.46 \pm 5.44 \%)$ compared to the other treatments (Tukey, $\mathrm{P}<0.05$ ). The multiple comparisons test displayed that the means differences within the salinity groups were significant (Tukey, $\mathrm{P}<0.05$ ). In the latter species no hatching was observed at salinities 10 and 15 gL ${ }^{-1}$ (Fig. 4).

The cumulative hatching percentage after 10 days of incubation of all species under the experimental
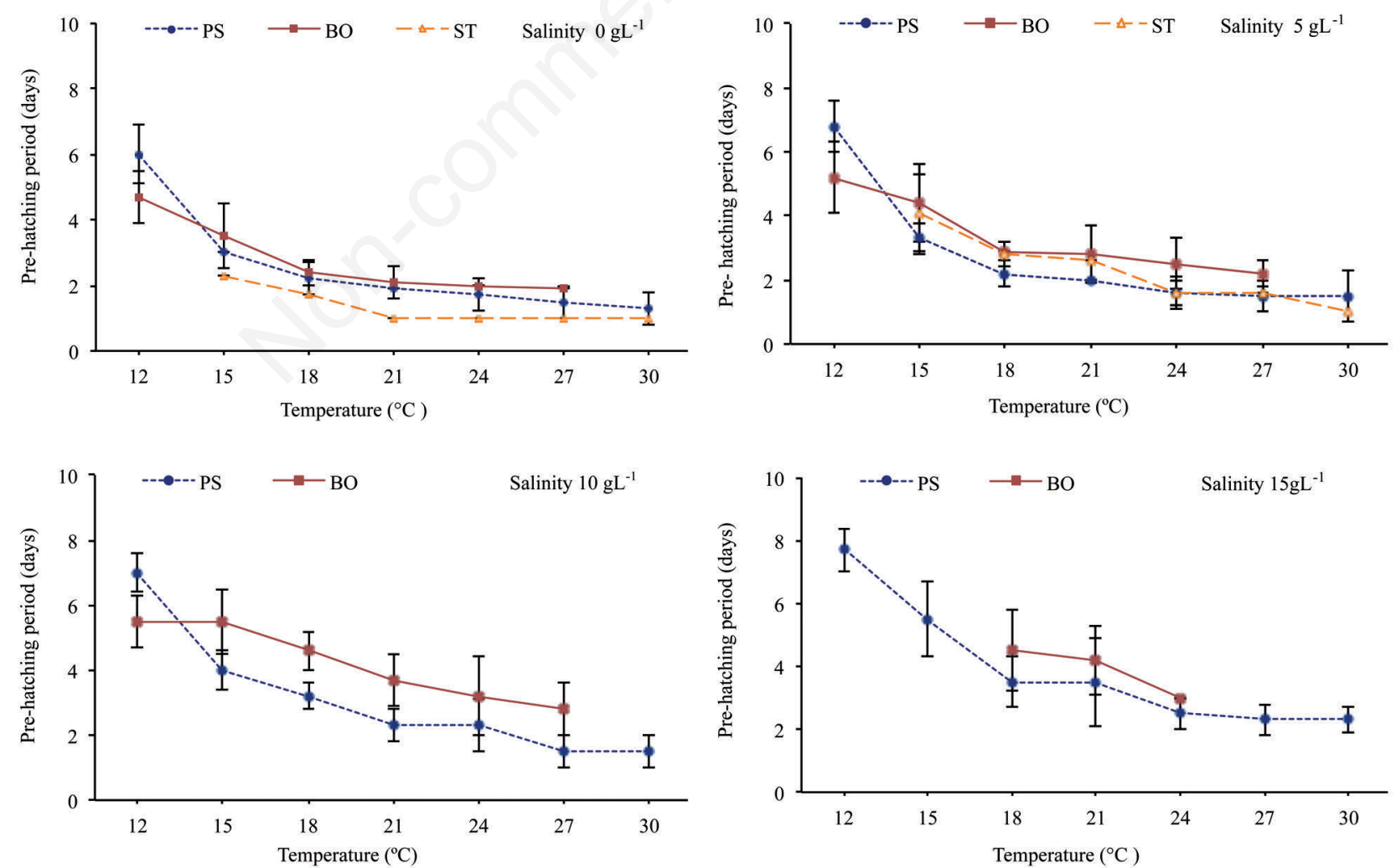

Fig. 2. The mean ( \pm standard deviation) pre-hatching period at different temperatures and salinities for the three studied species (PS, P. spinosa; BO, B. orientalis; $\mathrm{ST}, \mathrm{S}$. torvicornis) $(\mathrm{n}=6)$. 
conditions indicated that the linear and quadratic effects of the interaction of temperature and salinity were important factors influencing hatching percentage of these anostracan species. Contour analysis defined clear optimal combinations of temperature and salinity for the hatching of the studied species (Fig. 5). The optimal level of both temperature and salinity for hatching success of $P$. spinosa, B. orientalis and $S$. torvicornis were $19-25^{\circ} \mathrm{C}$; $18-23^{\circ} \mathrm{C}$ and $16-20^{\circ} \mathrm{C}$, respectively, combined with a salinity range of $0-1 \mathrm{gL}^{-1}$ for the three species.

\section{DISCUSSION}

Our results showed that hatching was more successful in lower salinities and that an increase in salinity had a negative effect on the cumulative hatching and on the initial hatching fraction of the fairy shrimp species being studied. This finding is supported by constant observation of the hatching process in nature which mostly took place when water salinity dropped to near zero. Negative responses of freshwater invertebrates to salinity are reported for various species of Anostraca, copepods and cladocerans (Timms and Sanders, 2002; Brock et al., 2005; Pinder et al., 2005; Waterkeyn et al., 2010). Also the importance of temperature for anostracan egg hatching has been demonstrated by several authors (Belk and Cole, 1975; Horne, 1967; Hathaway and Simovich, 1996). In Artemia hatching occurs within certain temperature limits (15-37 $\left.{ }^{\circ} \mathrm{C}\right)$ (Vanhaecke et al., 1984; Vanhaecke and Sorgeloos, 1989; Triantaphyllidis et al., 1994). However, the role of salinity appears to complicate the temperature effect. When Artemia eggs are exposed to different stressors, such as salinity and temperature, for a relatively long period, the combined effect of the two stressors may be negative (Vanhaecke and Sorgeloos, 1989). Temperature tolerance in Artemia (in the range $25-37^{\circ} \mathrm{C}$ ) was clearly affected by salinity, though differences between Artemia species were observed.

All three species showed a significant temperaturesalinity interaction effect for the duration of the pre-hatching period and for the hatching percentage at first hatching. Based on contour plot analysis maximum predicted hatching for $P$. spinosa, B. orientalis and $S$. torvicornis occurred at temperature ranges $19-25^{\circ} \mathrm{C}, 18$ $23^{\circ} \mathrm{C}$ and $16-20^{\circ} \mathrm{C}$ respectively, at the salinity range of $0-1$ $\mathrm{gL}^{-1}$. Comprehensive information is available on the specific temperature range or regime for optimal hatching performance of various anostracan species; for some

Tab. 3. ANOVA analyses testing the effects of temperature and salinity on hatching percentage at first day of hatching.

\begin{tabular}{|c|c|c|c|c|c|}
\hline Species & $\begin{array}{l}\text { Source of } \\
\text { variation }\end{array}$ & $\begin{array}{c}\text { Degrees of } \\
\text { freedom }\end{array}$ & $\begin{array}{l}\text { Mean sum of } \\
\text { squares }\end{array}$ & $\begin{array}{c}\mathrm{F} \\
\text { value }\end{array}$ & $\begin{array}{c}\mathrm{P} \\
\text { value }\end{array}$ \\
\hline B. orientalis & $\begin{array}{c}\text { Temperature } \\
\text { Salinity } \\
\text { Temperaturexsalinity }\end{array}$ & $\begin{array}{c}6 \\
3 \\
18\end{array}$ & $\begin{array}{c}1352.45 \\
5912.68 \\
531.45\end{array}$ & $\begin{array}{c}11.36 \\
49.69 \\
4.47\end{array}$ & $\begin{array}{l}\mathrm{P}<0.001 \\
\mathrm{P}<0.001 \\
\mathrm{P}<0.001\end{array}$ \\
\hline P. spinosa & $\begin{array}{c}\text { Temperature } \\
\text { Salinity } \\
\text { Temperaturexsalinity }\end{array}$ & $\begin{array}{c}6 \\
3 \\
18\end{array}$ & $\begin{array}{c}3790.25 \\
7667.84 \\
789.16\end{array}$ & $\begin{array}{c}13.63 \\
27.58 \\
2.83\end{array}$ & $\begin{array}{l}\mathrm{P}<0.001 \\
\mathrm{P}<0.001 \\
\mathrm{P}<0.001\end{array}$ \\
\hline S. torvicornis & $\begin{array}{c}\text { Temperature } \\
\text { Salinity } \\
\text { Temperaturexsalinity }\end{array}$ & $\begin{array}{c}6 \\
3 \\
18\end{array}$ & $\begin{array}{c}704.92 \\
8778.84 \\
458.85\end{array}$ & $\begin{array}{c}12.37 \\
154.13 \\
8.04\end{array}$ & $\begin{array}{l}\mathrm{P}<0.001 \\
\mathrm{P}<0.001 \\
\mathrm{P}<0.001\end{array}$ \\
\hline
\end{tabular}

Tab. 4. ANOVA analyses testing the effects of temperature and salinity on cumulative hatching percentage on day 10 .

\begin{tabular}{|c|c|c|c|c|c|}
\hline Species & $\begin{array}{l}\text { Source of } \\
\text { variation }\end{array}$ & $\begin{array}{c}\text { Degrees of } \\
\text { freedom }\end{array}$ & $\begin{array}{l}\text { Mean sum of } \\
\text { squares }\end{array}$ & $\begin{array}{c}\mathrm{F} \\
\text { value }\end{array}$ & $\begin{array}{c}\mathrm{P} \\
\text { value }\end{array}$ \\
\hline \multirow[t]{3}{*}{ B. orientalis } & Temperature & 6 & 5473.79 & 23.06 & $\mathrm{P}<0.001$ \\
\hline & Salinity & 3 & 17201.64 & 72.42 & $\mathrm{P}<0.001$ \\
\hline & Temperaturexsalinity & 18 & 860.37 & 3.62 & $\mathrm{P}<0.001$ \\
\hline \multirow[t]{3}{*}{ P. spinosa } & Temperature & 6 & 10186.02 & 39.96 & $\mathrm{P}<0.001$ \\
\hline & Salinity & 3 & 22540.79 & 72.99 & $\mathrm{P}<0.001$ \\
\hline & Temperaturexsalinity & 18 & 1139.06 & 4.17 & $\mathrm{P}<0.001$ \\
\hline \multirow[t]{3}{*}{ S. torvicornis } & Temperature & 6 & 2101.76 & 38.38 & $\mathrm{P}<0.001$ \\
\hline & Salinity & 3 & 19602.66 & 358.02 & $\mathrm{P}<0.001$ \\
\hline & Temperaturexsalinity & 18 & 1001.04 & 18.28 & $\mathrm{P}<0.001$ \\
\hline
\end{tabular}


species the range is as narrow as about $1{ }^{\circ} \mathrm{C}$ (e.g., Branchinecta lindahli Packard 1883, Branchinecta paludosa O.F. Müller, 1788, Streptocephalus dichotomus Baird, 1860 and Streptocephalus seali Ryder, 1879) while for others it is broader, up to $5^{\circ} \mathrm{C}$ (e.g., Branchinecta packardi Pearse 1912, Streptocephalus dorothae J. G. Mackin, 1942, Streptocephalus mackini W.G. Moore,
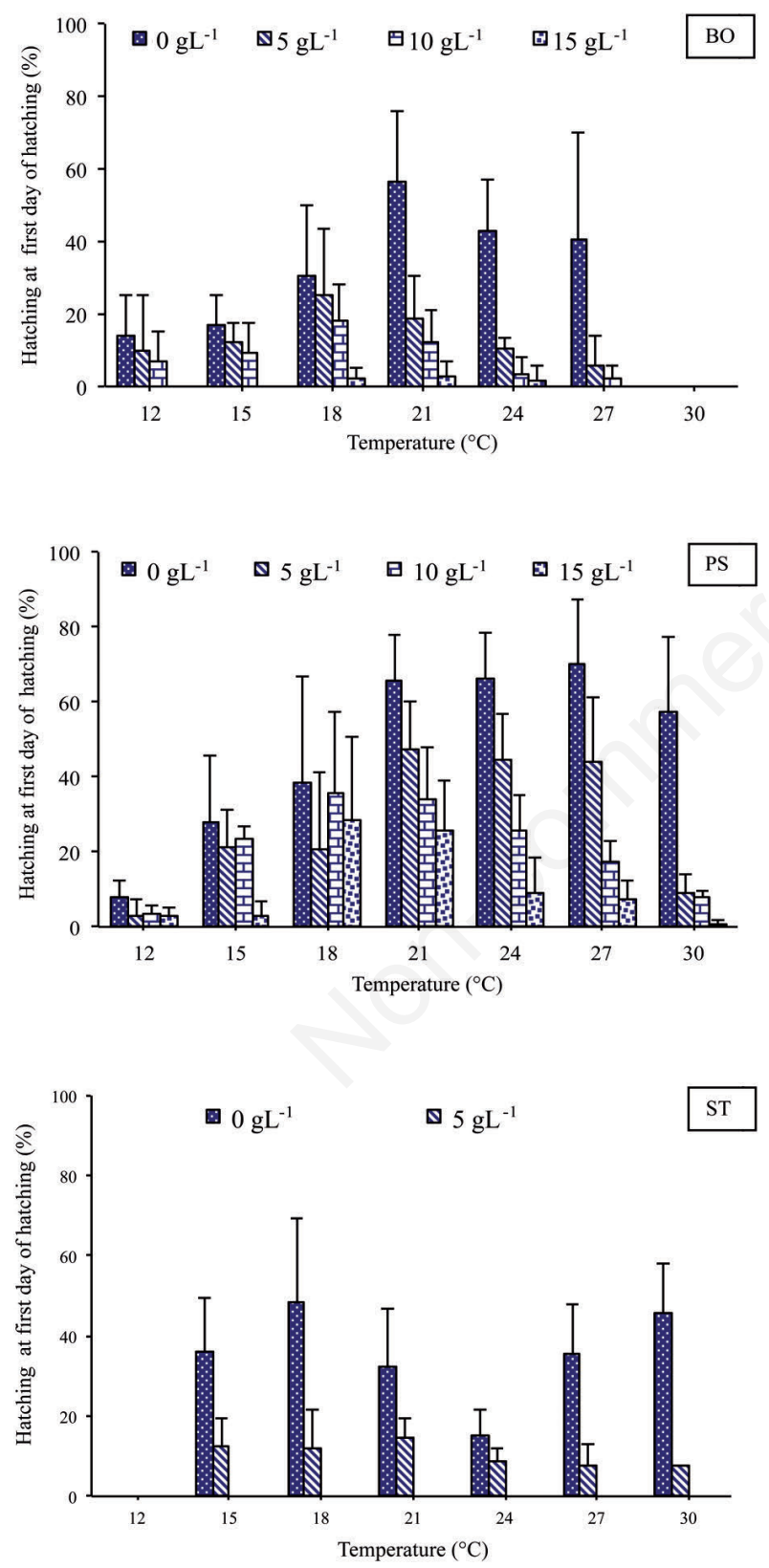

Fig. 3. The mean ( \pm SD standard deviation) hatching percentage at the first day of hatching at different temperatures and salinities for three species (PS, P. spinosa; BO, B. orientalis; $\mathrm{ST}, \mathrm{S}$. torvicornis $)(\mathrm{n}=6)$.
1966, Streptocephalus macrourus Daday, 1908) (Brendonck, 1996). However, we also found that $P$. spinosa was able to hatch at wider ranges of temperature and salinity compared to the other two species. Although the optimum temperatures and salinities usually can be estimated from the raw data, the statistical technique (surface response contour) used in this study allows to
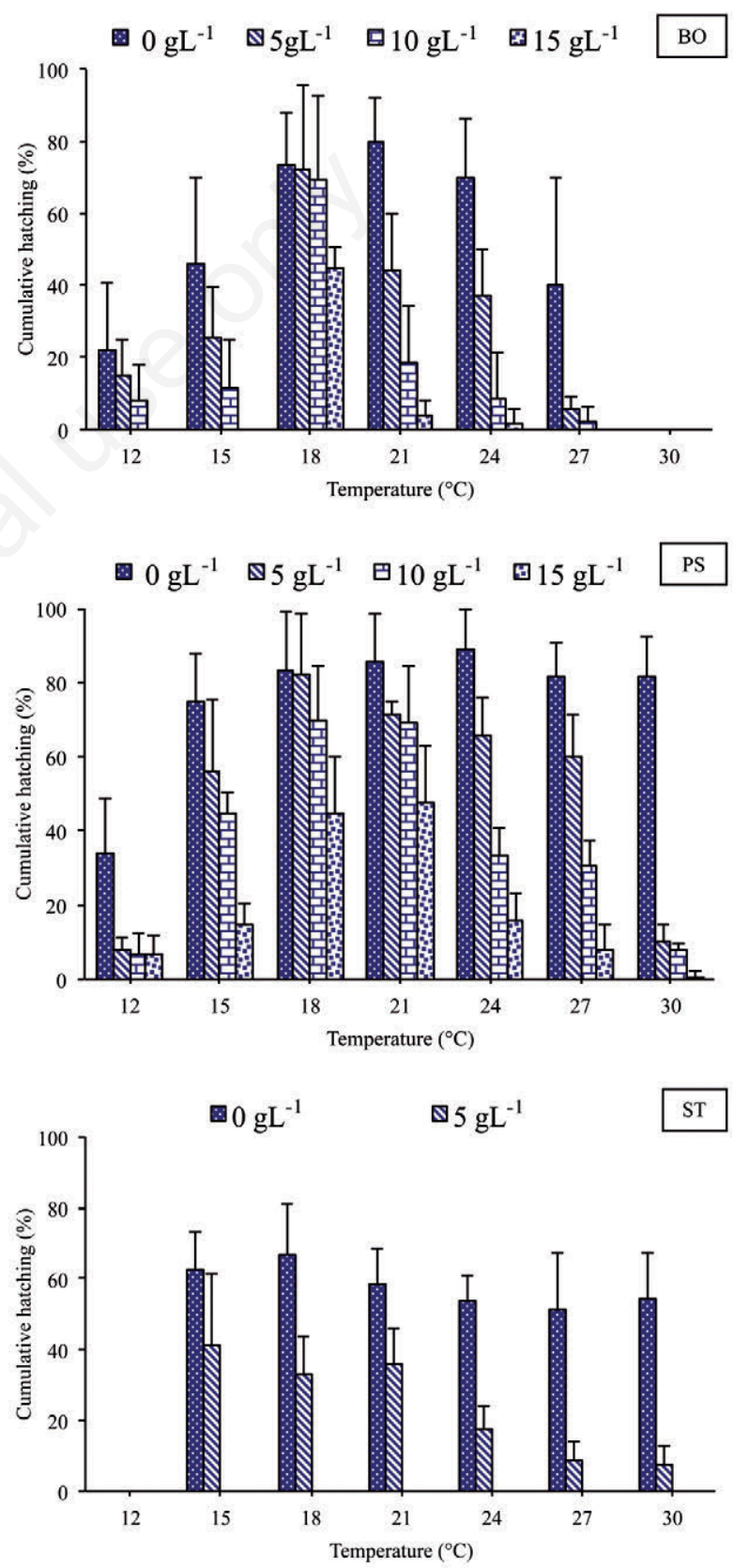

Fig. 4. The mean $( \pm \mathrm{SD}$ standard deviation) cumulative hatching percentage at different temperatures and salinity for three species (PS, P. spinosa; BO, B. orientalis; $\mathrm{ST}$, S. torvicornis) $(\mathrm{n}=6)$. 
define and interpret the hatching response of fairy shrimps to a matrix of environmental factors and to determine whether the responses are different for tested organisms. In the present study, the optimal temperature and salinity for maximum hatching of $P$. spinosa eggs was $24^{\circ} \mathrm{C}$ and $0 \mathrm{gL}^{-1}$ (up to $88 \%$ ) and the initial hatching fraction was about $70 \%$ at this salinity and $27^{\circ} \mathrm{C}$. Our findings were different from results obtained by Hulsmans et al. (2006) on $P$. spinosa from Sua Pan in Botswana, who reported highest cumulative hatching percentage (up to $85 \%$ ) at $22^{\circ} \mathrm{C}$ at a salinity of $5 \mathrm{gL}^{-1}$ with an initial hatching fraction of about $30 \%$ at salinity $5 \mathrm{gL}^{-1}$. However, Dararat et al. (2011) obtained almost similar results in Branchinella thailandensis Sanoamuang, Saengphan and Murugan 2002 , compared to our findings. They reported the highest hatching percentage (up to $87 \%$ ) after 7 days of incubation at $24-26^{\circ} \mathrm{C}$ and $0 \mathrm{gL}^{-1}, 75 \%$ of which occurred in the first day. The pre-hatching period in our study ranged from 1 day at $30^{\circ} \mathrm{C}$ and $0 \mathrm{gL}^{-1}$, to 5.5 days at 12 $15^{\circ} \mathrm{C}$ and $10 \mathrm{gL}^{-1}$. The hatching was slowest to start at the combination of the lowest temperature $\left(12^{\circ} \mathrm{C}\right)$ and highest salinity $\left(15 \mathrm{gL}^{-1}\right)$. A similar performance has been reported for the specimens from Botswana, ranging from 1.0 day after inundation at $32^{\circ} \mathrm{C}$ and $0 \mathrm{gL}^{-1}$, to 6.4 days at $14^{\circ} \mathrm{C}$ and $10 \mathrm{gL}^{-1}$. Intraspecific variation in the hatching pattern of fairy shrimps is also reported by a number of other researchers confirming the above findings on $P$. spinosa (see review in Brendonck, 1996; Simovich and Hathaway, 1997; Van Dooren and Brendonck, 1998; Brendonck and Riddoch, 2001). However, it should be taken into account that recent data (Ketmaier et al., 2008, Alonso and Ventura, 2013; Ketmaier et al., 2013) suggest that $P$. spinosa is not monophyletic. Therefore further studies may be required to confirm if differences in hatching patterns are indeed due to intraspecific variations or if they are phylogenetic differences.

In the same sense, S. torvicornis can be compared with other species of the genus Streptocephalus (Streptocephalus purcelli G.O. Sars, 1898; Streptocephalus sirindhornae Sanoamuang, Murugan, Weekers and Dumont 2000; Streptocephalus siamensis Sanoamuang and Saengphan 2006). In our study, the highest hatching in S. torvicornis (up to $67 \%$ ) was detected at $18^{\circ} \mathrm{C}$ and $0 \mathrm{gL}^{-1}$. These findings are quite different from the hatching characteristics of S. purcelli $(75 \%$ and $32 \%)$ at $13{ }^{\circ} \mathrm{C}$ and $0 \mathrm{gL}^{-1}$ from a South African rock-pool and mud-pool, respectively (De Roeck et al., 2010). Results obtained by Dararat et al. (2011) on hatching characteristics of $S$. sirindhornae and $S$. siamensis $(64 \%$ and $50 \%$, respectively, at $24-26^{\circ} \mathrm{C}$ and $0 \mathrm{gL}^{-1}$ ) show a pattern of hatching characteristics different from earlier studies. In the current study the eggs of $S$. torvicornis hatched within 1.7 days after inundation at $18^{\circ} \mathrm{C}$ and $0 \mathrm{gL}^{-1}$, but at higher temperatures $\left(21-30^{\circ} \mathrm{C}\right)$ hatching started earlier
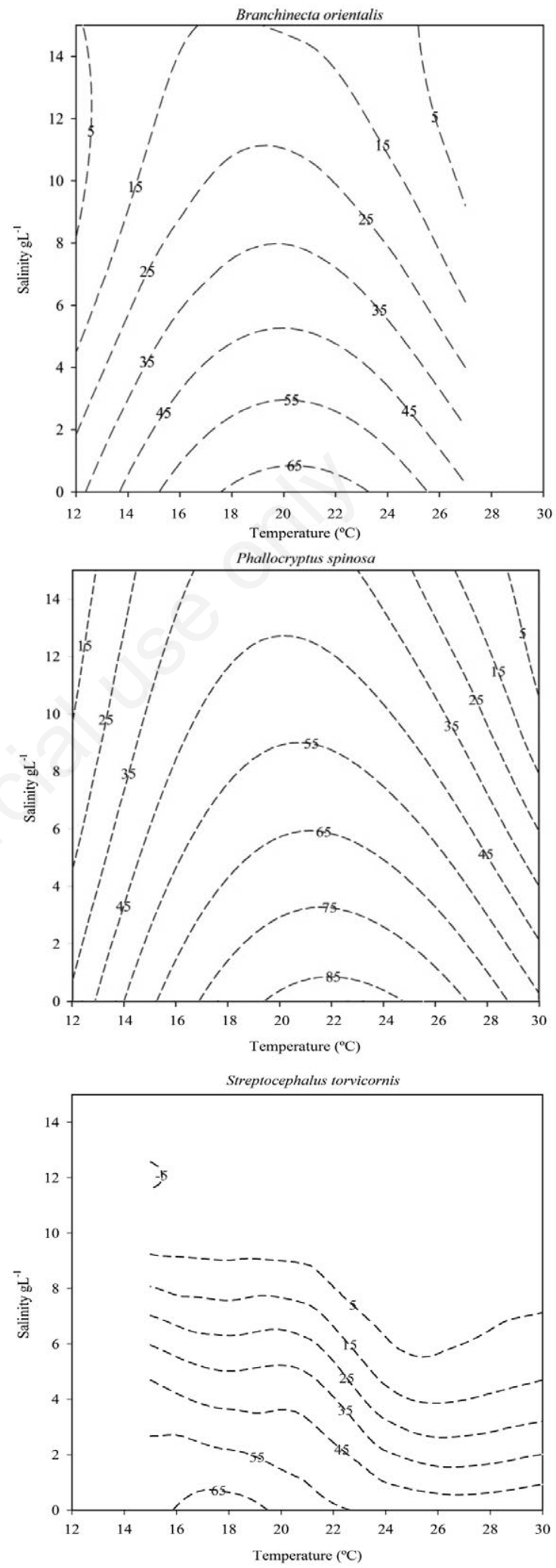

Fig. 5. Response surface estimation of cumulative hatching percentage (contour lines) of three species of Anostraca after 10 days of inundation at different experimental temperature and salinity combinations. 
(immediately after day 1) at the same salinity. In contrast to our findings, hatching in S. purcelli from a rock-pool and a mud-pool started 1 and 2 days, respectively, after inundation at $13^{\circ} \mathrm{C}$ and $0 \mathrm{gL}^{-1}$ (De Roeck et al., 2010) and started to hatch 1 day after inundation at $24-26^{\circ} \mathrm{C}$ and $0 \mathrm{gL}^{-1}$ in both $S$. sirindhornae and S. siamensis (Dararat et $a l ., 2011)$. Summarizing the results obtained by different authors proves that species-specific optimal factors are needed for optimal hatching in different species of fairy shrimps.

In all the species tested the duration of the prehatching period was directly proportional to salinity and inversely proportional to temperature. The hatching process continued during the following 10 days, especially under low salinity conditions, supporting the findings of Brendonck (1996) and Brown and Carpelan (1971) on hatching strategy. In many species, hatching extends over several days or even weeks even under favourable conditions. The highest peak, however, is generally on the first or second day of hatching (Brendonck, 1996). Bet-hedging is a strategy employed by many inhabitants of temporary waters, and ensures that not all juveniles emerge before the hydroperiod has become properly established (Williams, 2006). The hatching fraction is expected to be adjusted to the probability of successful completion of the life cycle before drying of the pans (Ellner, 1985; Mura, 2004; Hulsmans et al., 2006; Dararat et al., 2011). Several studies have demonstrated the spreading of the risk of a demographic catastrophe by partial delayed hatching of the anostracan egg bank (Simovich and Hathaway, 1997; Brendonck et al., 1998; Mura and Zarattini, 1999). At each inundation, only part of the egg bank hatches, while the rest serves as a buffer in case insufficient hydroperiod remains to complete the life cycle. The variability in hatching response even occurs in single broods and can, therefore, be considered as a diversified bet-hedging strategy (Simovich and Hathaway, 1997; Van Dooren and Brendonck, 1998).

Combining anostracan hatching conditions with climatic data can explain the phenology of anostracans in this study area. Based on our field observations the fairy shrimps do not appear until the end of February depending on the average temperature and the amount of flooding required to fill the biotopes and to decrease salinity levels. In most cases temperature was found to be an important parameter influencing the appearance of anostracans. At the beginning of the spring when the air temperature reaches up to $12^{\circ} \mathrm{C}$, only $B$. orientalis is found. P. spinosa gradually appear in April when the average temperature rises above $12-14^{\circ} \mathrm{C}$. S. torvicornis occurs in the field when the temperature is over $15^{\circ} \mathrm{C}$ at the end of May (own observations). Temperature drops again to optimal ranges required for hatching in September-October, but recruitment fails in this period most likely due to high water salinity. These findings are in agreement with our laboratory results and explain the specific performance of each species with reference to the effect of salinity and temperature.

\section{CONCLUSIONS}

We may conclude that $P$. spinosa is more tolerant to high temperature and salinity levels than the other species. However there was not so much difference between the species in tolerance for low temperature and salinity. This study also showed that salinity is a more important parameter than temperature, as it affects the hatching rate of all species. It should be noted that both East and West Azerbaijan and especially the Lake Urmia region are suffering from drought since 1998, as a result of which over $80 \%$ of Lake Urmia has dried and salt storms have caused salinization of the surrounding areas including the anostracans habitats. Most of the pools inhabited by fairy shrimps are located in the vicinity of the Lake Urmia and are naturally affected by soil salinity in varying degrees. This along with incomplete filling of the pools is likely to result in high water salinity. Moreover, climate change in this region has resulted in an increase of temperature by $1.5^{\circ} \mathrm{C}$ compared to long-term temperature records, causing a further increase in salinity as a result of higher evaporation levels (Masoodian, 2004). Therefore, it seems that increasing salinity has been acting as an inhibiting factor on hatching performance of the anostracans living in this area.

\section{ACKNOWLEDGMENTS}

The authors are grateful to the Artemia and Aquatic Animals Research Institute of Urmia University, Iran, for providing research facilities.

\section{REFERENCES}

Abatzopoulos TJ, El-Bermawi N, Vasdekis C, Baxevanis AD, Sorgeloos P, 2003. Effect of salinity and temperature on reproductive and life span characteristics of clonal Artemia. (International Study on Artemia. LXVI). Hydrobiologia 492:191-199.

Alonso M, Ventura M, 2013. A new fairy shrimp Phallocryptus tserensodnomi (Branchiopoda: Anostraca) from Mongolia. Zootaxa 3670:349-361.

Atashbar B, Agh N, Beladjal L, Jalili R, Mertens J, 2012. Effects of temperature on survival, growth, reproductive and life span characteristics of Branchinecta orientalis G.O. Sars 1901 (Branchipoda: Anostraca) from Iran. Crustaceana 85:1099-1114.

Atashbar B, Agh N, Van Stappen G. Beladjal L, 2014. Diversity and distribution patterns of large branchiopods (Crustacea: Branchiopoda) in temporary pools (Iran). J. Arid Environ 111:27-34

Belk D, Cole GA, 1975. Adaptational biology of desert 
temporary pond inhabitants, p. 207-226. In: N.F. Hadley (ed.), Environmental physiology of desert organisms. Dowden, Hutchinson and Ross Inc.

Bohonak AJ, Roderick GK, 2001. Dispersal of invertebrates among temporary ponds: are genetic estimates accurate? Israel J. Zool. 47:367-386.

Bond RM, 1934. Report on phyllopod crustacea (Anostraca, Notostraca and Conchostraca) including a revision of the Anostraca of the Indian Empire. Mem. Conn. Acad. Arts Sci. 10:29-62.

Brendonck L, 1996. Diapause, quiescence, hatching requirements: what we can learn from large freshwater branchiopods (Crustacea: Anostraca, Notostraca, Conchostraca). In: V.R. Alekseev and G. Fryer (eds.), Diapause in the Crustacea. Hydrobiologia 320:85-97.

Brendonck L, Centeno MD, Persoone G, 1996. The influence of processing and temperature conditions on hatching of resting eggs of Streptocephalus proboscideus Frauenfeld, 1873. Hydrobiologia 320:99-105.

Brendonck L, Riddoch BJ, 2001. Hatching characteristics of the fairy shrimp Branchipodopsis wolfi (Daday, 1910) in relation to the stochastic nature of its habitat, desert rock pools. Arch. Hydrobiol. 52:141-161.

Brendonck L, Riddoch BJ, Van de Weghe V, Van Dooren T, 1998. The maintenance of egg banks in very short-lived pools - a case study with anostracans (Branchiopoda). Arch. Hydrobiol. (Spec. Issue) 52:141-161.

Brock MA, Nielsen DL, Crossle K, 2005. Changes in biotic communities developing from freshwater wetland sediments under experimental salinity and water regimes. Freshwater Biol. 50:1376-1390.

Brown LR, Carpelan LH, 1971. Egg hatching and life history of a fairy shrimp Branchinecta mackini Dexter, 1956 (Crustacea: Anostraca) in a Mojave Desert playa (rabbit dry lake). Ecology 52:41-54.

Coulson SJ, Hodkinson ID, Webb NR, Harrison JA, 2002. Survival of terrestrial soil-dwelling arthropods on and in seawater: implications for transoceanic dispersal. Funct. Ecol. 16:353-356.

Dararat W, Starkweather PL, Sanoamuang L, 2011. Life history of three fairy shrimps ( Branchiopoda: Anostraca) from Thailand. J. Crustacean Biol. 31:623-629.

De Roeck E, Waterkeyn A, Brendonck L, 2010. Life-history traits of Streptocephalus purcelli G.O. Sars, 1898 (Branchiopoda, Anostraca) from temporary waters with different phenology. Water SA 36:323-328.

Ellner S, 1985. ESS germination strategies in randomly varying environments. 1. Logistic-type models. Theor. Popul. Biol. 28:50-79.

Figuerola J, Green AJ, Santamaria L, 2003. Passive internal transport of aquatic organisms by waterfowl in Doñana, south-west Spain. Global Ecol. Biogeogr. 12:427-436.

Frank PW, 1988. Conchostraca. Paleogeogr. Paleoecol. 62: 399-403.

Garcia-Roger EM, Carmona MJ, Serra M, 2006. A simple model relating habitat features to a diapause egg bank. Limnol. Oceanogr. 51:1542-1547.

Gottwald R, Eder E, 1999. [«Co-occurence»-ein Beitrag zur Synökologie der Groß-Branchiopoden].[Article in German]. Ann. Naturhistor. Mus. Wien 101B:465-473.
Green AJ, Figuerola J, 2005. Recent advances in the study of long-distance dispersal of aquatic invertebrates via birds. Divers. Distrib. 11:149-156.

Green AJ, Sanchez MI, Amat F, Figuerola J, Hontoria F, Ruiz O, Hortas F, 2005. Dispersal of invasive and native brine shrimps Artemia (Anostraca) via waterbirds. Limnol. Oceanogr. 50:737-742.

Grice GD, Marcus NH, 1981. Dormant eggs of marine copepods. Oceanogr. Mar. Biol. 19:125-140.

Hairston NG, Cáceres CE, 1996. Distribution of crustacean diapause: micro- and macroevolutionary pattern and process. Hydrobiologia 320:27-44.

Hansen BW, Drillet G, Kozmér RA, Madsen KV, Pedersen MF, Sørensen TF, 2010. Temperature effects on copepod egg hatching: does acclimatization matter? J. Plankton Res. 32:305-315.

Hathaway SA, Simovich MA, 1996. Factors affecting the distribution and co-occurrence of two southern California anostracans (Branchiopoda), Branchinecta sandiegonensis (Fugate, 1993) and Streptocephalus woottoni Eng, Belk, Eriksen, 1990. J. Crust. Biol. 16:669-677.

Horne FR, 1967. Effects of physical-chemical factors on the distribution and occurrence of some southeastern Wyoming phyllopods. Ecology 48:472-477.

Hulsmans A, Bracke S, Moreau K, Riddoch BJ, De Meester L, Brendonck L, 2006. Dormant egg bank characteristics and hatching pattern of the Phallocryptus spinosa MilneEdwards, 1840 (Anostraca) population in the Makgadikgadi Pans (Botswana). Hydrobiologia 571:123-132.

Hulsmans A, Vanschoenwinkel B, Pyke C, Riddoch BJ, Brendonck L, 2008. Quantifying the hydroregime of a temporary pool habitat: a modelling approach for ephemeral rock pools in SE Botswana. Ecosystems 11:89-100.

Ketmaier V, Pirollo D, De Matthaeis E, Tiedemann R, Mura G, 2008. Large-scale mitochondrial phylogeography in the halophilic fairy shrimp Phallocryptus spinosa (MilneEdwards, 1840) (Branchiopoda: Anostraca). Aquat. Sci. 70:65-76.

Ketmaier V, Pirollo D, De Matthaeis E, Tiedemann R, Mura G, 2013. Erratum to: Large-scale mitochondrial phylogeography in the halophilic fairy shrimp Phallocryptus spinosa (MilneEdwards, 1840) (Branchiopoda:Anostraca). Aquat. Sci. 75: 333-334.

Longhurst AR, 1955. A review of the notostraca. Bull.br. Mus. nat. Hist. Zool. 3:1-57.

Lubzens E, Fishler R, Berdugo WV, 1980. Induction of sexual reproduction and resting egg production in Brachionus plicatilis (Müller, 1786) reared in sea water. Hydrobiologia 73:55-58.

Marcus NH, 1996. Ecological and evolutionary significance of resting eggs in marine copepods:past, present, and future. Hydrobiologia 32:141-152.

Masoodian SA, 2004. Trend of temperature in Iran during last half- century. J. Geogr. Dve. 3:89-106.

Mehdizadeh Fanid L, Seidgar M, Azari Takami G, 2007. A comparative SEM morphological study on the egg shell in some Anostracans (Crustacea: Branchiopoda) from East Azerbaijan Province of Iran. Iran J. Fish Sci. 7:101-110.

Merta L, 2003. Prehatching success of Eubranchipus (Siphonophanes) grubii dybowski 1860 (Crustacea, 
Anostraca) under the influence of some environmental factors. Biol. Brat. 58:919-924.

Munuswamy N, Satyanarayana S, Priyadarshini A, 2009. Embryonic development and occurrence of p26 and arteminlike protein in the cryptobiotic cysts of freshwater fairy shrimp, Streptocephalus dichotomus Baird, 1860. Curr. Sci. 96:103-110.

Mura G, 2004. Structure and functioning of the "egg bank" of a fairy shrimp in a temporary pool: Chirocephalus ruffoi (Cottarelli, Mura, 1984) from Pollino National Park (Southern Italy) as a case study. Int. Rev. Hydrobiol. 89:35-50.

Mura G, Azari Takami G, 2000. A contribution to the knowledge of the anostracan fauna of Iran. Hydrobiologia 441:117-121.

Mura G, Zarattini P, 1999. Influence of parental rearing conditions on cyst production and hatching of Chirocephalus ruffoi (Cottarelli, Mura, 1984) an endemic fairy shrimp from Italy. Crustaceana 72:449-465.

Nielsen DL, Brock MA, Crosslé K, Harris K, Healey M, Jarosinski I, 2003. The effect of salinity on aquatic plant germination and zooplankton hatching from two wetland sediments. Freshwater Biol. 48:2214-2223.

Pinder MA, Halse SA, Mcrae JM, Shiel J, 2005. Occurrence of aquatic invertebrates of the wheat-belt region of western Australia in relation to salinity. Hydrobiologia 543:1-24.

Pourriot R, Snell TW, 1983. Resting eggs in rotifers. Hydrobiologia 104:213-224.

Proctor VW, 1964. Viability of crustacean eggs recovered from ducks. Ecology 45:656-658.

Proctor VW, Malone CR, Devlaming VL, 1967. Dispersal of aquatic organisms: viability of disseminules recovered from the intestinal tract of captive Killdeer. Ecology 48:672-676.

Simovich MA, Hathaway SA, 1997. Diversified bet-hedging as a reproductive strategy of some ephemeral pool anostracans (Branchiopoda). J. Crust. Biol. 17:38-44.

Sorgeloos P, Bossuyt E, Laviña E, Baeza-Mesa M, Persoone G, 1980. Decapsulation of Artemia cysts: A simple technique for the improvement of the use of brine shrimp in aquaculture. Aquaculture 12:311-315.

Timms BV, Sanders PR, 2002. Biogeography and ecology of Anostraca (Crustacea) in middle Paroo catchment of the
Australian arid-zone. Hydrobiologia 486:225-238.

Triantaphyllidis GV, Pilla E, Thomas K, Abatzopoulos TJ, Beardmore JA, Sorgeloos P, 1994. International study on Artemia. LII. Incubation of Artemia cyst samples at high temperatures reveals mixed nature with Artemia franciscana (Kellogg, 1906) cysts. J. Exp. Mar. Biol. Ecol. 183:273-282.

Van Dooren T, Brendonck L, 1998. The hatching pattern of Branchipodopsis wolfi Daday, 1910 (Crustacea: Anostraca): phenotypic plasticity, additive genetic and maternal effects Arch. Hydrobiol. 52:219-227.

Van Stappen G, 1996. Use of cysts, p. 107-136. in: P. Lavens and P. Sorgeloos (eds), Manual on the production and use of live food for aquaculture. FAO Fisheries Technical Paper 361.

Vanhaecke P, Siddall E, Sorgeloos P, 1984. International study on Artemia. XXXII. Combined effects of temperature and salinity on the survival of Artemia of various geographical origins. J. Exp. Marine Biol. Ecol. 80:259-275.

Vanhaecke P, Sorgeloos P, 1989. International study on Artemia. XLVII. The effect of temperature on cyst hatching, larval survival and biomass production for different geographical strains of brine shrimp Artemia spp. Ann. Soc. R. Zool. Belg. 119:7-23.

Viitasalo M, 1992. Calanoid resting eggs in the Baltic Sea: implications for the population dynamics of Acartia bifilosa Giesbrecht, 1881 (Copepoda). Mar. Biol. 114:397-405.

Waterkeyn A, Vanschoenwinkel B, Patrick G, Brendonck L, 2010. Effect of salinity on seasonal community patterns of Mediterranean temporary wetland crustaceans: a mesocosm study. Limnol. Oceanogr. 55:1712-1722.

Williams DD, 2006. The biology of temporary waters. Oxford University Press: 337 pp.

Zarattini P, 2004. Intraspecific differences in hatching phenology of the fairy shrimp Chirocephalus diaphanus Prévost, 1803 (Crustacea, Anostraca) in relation to habitat duration. J. Limnol. 63:85-89.

Zarattini P, Mura G, 2007. Co-occurrence of free-swimming and quiescent nauplii in a spring hatching of two Chirocephalus diaphanus Prévost, 1803 (Anostraca) populations from mountain pasture pools. Crustaceana 80:707-715. 